\title{
Biodiversity Conservation Needs and Method to Conserve the Biological Diversity
}

Joseph Wanjui*

Al-Farabi Kazakh National University, Kazakhstan

\section{What is Biodiversity and what are the Threats for it?}

Biodiversity is the biological diversity which includes the variety of the whole species present on earth. It includes different animals, plants, micro-organisms and their genes, water ecosystems, terrestrial, and marine ecosystems in which they all are present.

Biodiversity is necessary for our existence as well as valuable in its own right. This is because it provides the fundamental building blocks for the many goods and services which provides a healthy environment to lead our life.

Biodiversity include fundamental things to our health like fresh water clean air and food products, as well as the many other products such as timber and fiber.

Biodiversity also includes various other important things and services such as cultural, recreational, and spiritual nourishment that play an important role in maintaining our personal life as well as social life.

So, it is an important task for all of us to take care of our Biodiversity and we should try to maintain it. Over the last 200 years Australia has suffered the largest ocumented decline in biodiversity of any continent. Despite efforts to manage threats and pressures to biodiversity in Australia, it is still in decline.

Main threats to our biodiversity are as given below:

- Degradation, fragmentation and loss of habitat

- Spreading of invasive species

- Unsustainable use of natural resources

- Change of Climate

- Inappropriate fire regimes

- Changes within aquatic environment and water flows

\section{Why should we Conserve Biodiversity?}

Human should conserve biodiversity because of its benefit for example services and biological resources which are essential to live our life on earth. However, it also provides spiritual benefits as well as social benefit.

\section{Biological Resources}

A biological resource means any product that is harvested from nature is the part of biological resources. These resources come under several categories such as medicine, food, wood products, fibers etc. For example under one category i.e., Food more than 7,000 species of plants are involved, although we dependent mainly on only 12 major crops for food.

For Medicinal field human population is dependent on plants. It is true that in the developed country, many of our medicines are produced by chemicals in pharmaceutical companies, but the original formulas come from plants. For example, aspirin is comes from willows, opiate which is a pain relievers is derived from poppies and quinine which is used for the treatment of malaria produced by the Cinchona tree.

Fibers which is used for ropes, clothing, webbing, netting, sacking, and other materials are obtained by plants mainly for example cotton plants, Agave plants (sisal), flax plants (linen), Corchorus plants (jute), bamboo, palms and Agave plants (sisal) (Figure 1).

\section{Ecosystem Services}

Ecosystem services means processes provided by the nature to support human life. For example Pollination, decomposition of waste, water purification, renewal of soil fertility and moderation of floods. Ecosystem processes are often overlooked, and are not generally valued as part of the economy until they cease to function. When economic value is assigned to these services, it becomes very high. For example, insect pollinators help produce many commercially important fruits such as almonds, melons, blueberries, and apples. The global economic value of pollination services performed by insects has been valued at $\$ 217$ billion per year.

Similarly in other ecosystem service water purification just involves filtering of rain water by soil and by microbes that can break down nutrients and contaminants, and reduce metal ions, slowing their spread into the environment. Wetland and riparian plants absorb nitrogen, and trap sediments that decrease water quality.

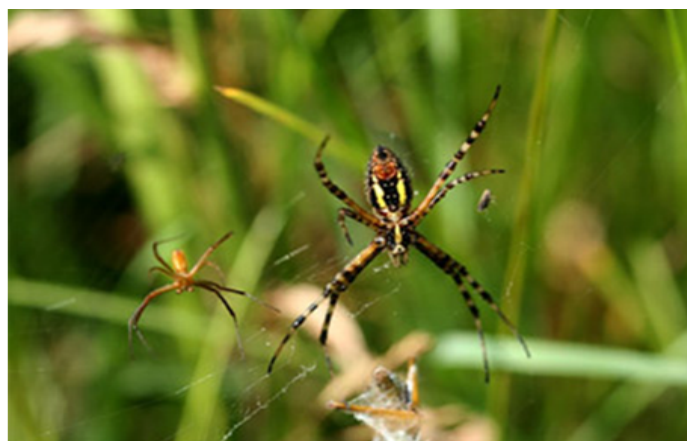

Figure 1: The tensile strength of the silk produce by spider provided a way to engineer to form a synthetic fabric. (This is a large female Argiope trifasciata spider has a male suitor)

*Corresponding author: Joseph Wanjui, Al-Farabi Kazakh National University Kazakhstan, E-mail: josephwanjui@yahoo.com

Received July 29, 2013; Accepted October 21, 2013; Published October 24 2013

Citation: Wanjui J (2013) Biodiversity Conservation Needs and Method to Conserve the Biological Diversity. J Biodivers Endanger Species 1: 113. doi: 10.4172/2332-2543.1000113

Copyright: (c) 2013 Wanjui J. This is an open-access article distributed under the terms of the Creative Commons Attribution License, which permits unrestricted use, distribution, and reproduction in any medium, provided the original author and source are credited. 
But human construction and development will disrupt natural environments as well all activity and services related to this environment. So finally we have to dependent on artificial man made services like for filtration we used different -different types of water filters and purifiers. For these artificial services we need to pay more while the natural ecosystem services are at free of cost

\section{Social and Spiritual Benefits}

Most of the time in human history, conservation means protecting nature for the spiritual gifts it provides, and protecting sacred places in the local landscape. The biodiversity effects on cultural development can be shown by heterogeneity of the world's mythology, folk dances and folk art which contribute to the richness of literature and global arts. In different landscapes, different cultures are present which influenced our language, diet, occupation and various types of activity.

Uniqueness of each habitat is presented by their animals and plants that why each country and state have their flagship animals as well as plants. Even during traveling, motivation of the peoples is to see biological diversity, different cultural and landscape. Ecotourism is travel with the aim to view, support and sustain the local cultures and its natural ecosystem. Support from ecotourism can be very helpful to reduce habitat destruction as well as to preserve endangered species.

\section{Biodiversity Conservation Methods}

\section{In-situ biodiversity conservation}

In-situ conservation means the conservation of species within their natural habitats, this way of conserving biodiversity is the most appropriate method for biodiversity conservation. In this strategy you have to find out the area with high biodiversity means the area in which number of plants and animals are present. After that this high biodiversity area should be covered in the form of natural park/ sanctuary/biosphere reserve etc. In this way biodiversity can be conserve in their natural habitat from human activities (Figure 2).

\section{Ex-Situ conservation methods}

Ex-situ conservation involves the conservation of biological diversity outside of their natural habitats. This involves conservation of genetic resources, as well as wild and cultivated or species, and draws on a diverse body of techniques and facilities.

Ex-situ Biodiversity conservation can be done as following:

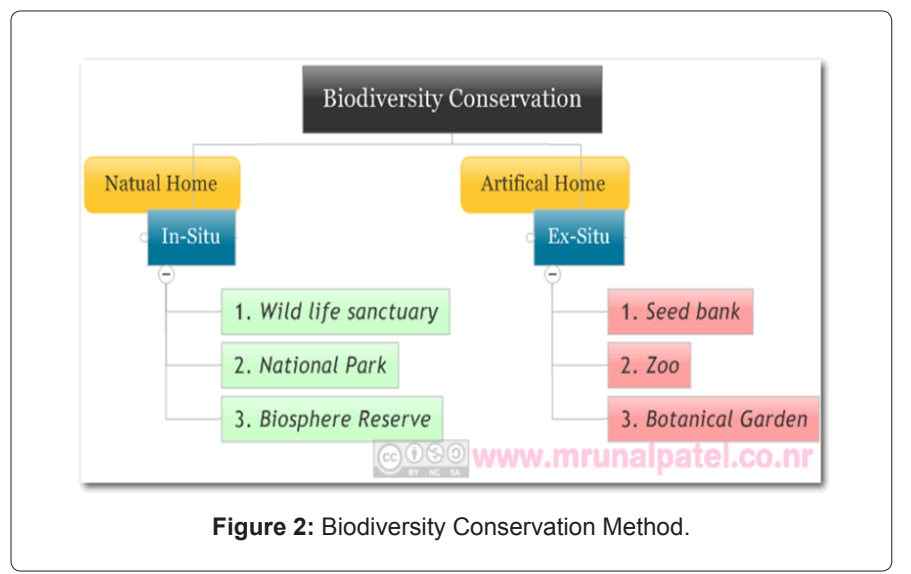

- By forming Gene banks: In this store seeds, sperm \& ova at extremely low temperature and humidity.

- It is very helpful to save large variety of species of plants \& animals in a very small space. e.g. sperm and ova banks, seed banks.

- Forming Zoo and botanical garden: for research purpose and to increase public awareness collecting living organisms for aquaria, zoos and botanic gardens.

- Collections of In vitro plant tissue and microbial culture.

- Captive breeding of animals and artificial propagation of plants, with possible reintroduction into the wild.

Ex-situ biodiversity conservation strategy also plays an important role in recovery programmes for endangered species. The Kew Seed Bank in England has 1.5 per cent of the world's flora - about 4,000 species - on deposit.

In agriculture, ex-situ conservation measures maintain domesticated plants which cannot survive in nature unaided.

It provides good platform for research opportunities on the components of biological diversity. Some of the institutions also play a major role in public education and in increasing awareness among public by bringing members of the public into contact with plants and animals they may not normally come in contact with. It is estimated over 600 million people visit zoos every year worldwide. 